\title{
Insulin resistance and hyperinsulinaemia in mild to moderate progressive chronic renal failure and its association with aerobic work capacity
}

\author{
I. Eidemak $^{1}$, B. Feldt-Rasmussen ${ }^{1}$, I.-L. Kanstrup ${ }^{2}$, S. L. Nielsen ${ }^{2}$, O. Schmitz ${ }^{3}$, S.Strandgaard ${ }^{1}$ \\ ${ }^{1}$ Department of Nephrology, Herlev University Hospital, Copenhagen, Denmark \\ ${ }^{2}$ Department of Clinical Physiology and Nuclear Medicine, Herlev University Hospital, Copenhagen, Denmark \\ ${ }^{3}$ Medical Department M (Diabetes and Endocrinology), Kommunehospitalet, University Hospital, Aarhus, Denmark
}

\begin{abstract}
Summary Tissue sensitivity to insulin and aerobic work capacity was measured in patients with mild to moderate progressive chronic renal failure. Twentynine non-diabetic patients with a glomerular filtration rate of $25 \mathrm{ml} \cdot \mathrm{min}^{-1} \cdot 1.73 \mathrm{~m}^{-2}(11-43)$ (median, range) and 15 sex, age, and body mass index matched control subjects with normal renal function were studied. Fasting blood glucose was comparable and in the non-diabetic range in the two groups as was the oral glucose tolerance test. Patients demonstrated hyperinsulinaemia both during fasting $(p<0.01)$ and during the test $(p<0.02)$. The tissue sensitivity to insulin, expressed by the amount of glucose infused during the last $60 \mathrm{~min}$ of a 120 -min hyperinsulinaemia euglycaemic clamp (M-value) and the $\mathrm{M} / \mathrm{I}$ ratio, was significantly lower in the patients than in the control subjects (M-value $404 \pm 118$ vs $494 \pm 85 \mathrm{mg}$ glucose $/ \mathrm{kg}$ body weight, $p<0.02)(\mathrm{M} / \mathrm{I}$
\end{abstract}

ratio $1.77 \pm 0.71$ vs $2.57 \pm 0.70(\mathrm{mg} /(\mathrm{kgBW} \cdot \mathrm{min})$ per $\mathrm{pmol} / \mathrm{l} \cdot 100, p<0.001)$. The maximal aerobic work capacity was significantly lower in the patients than in the control subjects $\left(24 \pm 8\right.$ vs $32 \pm 11 \mathrm{ml} \mathrm{O}_{2} /(\mathrm{kg}$ body weight $\cdot \min ), p<0.02$ ) and positively correlated to the $\mathrm{M}$-value and the $\mathrm{M} / \mathrm{I}$ ratio in both groups. In conclusion, not only patients with end-stage chronic renal failure but also those with mild to moderate progressive chronic renal failure are insulin resistant and hyperinsulinaemic. The tissue sensitivity to insulin is correlated to the maximal aerobic work capacity suggesting that these patients might benefit from physical training programmes. [Diabetologia (1995) 38: 565-572]

Key words Insulin resistance, hyperinsulinaemia, glucose tolerance, chronic renal failure, aerobic work capacity.
Insulin resistance, glucose intolerance and hyperinsulinaemia are present in end-stage chronic renal failure (CRF) [1-5] but have not previously been studied in patients with only mild to moderate progressive CRF. If present also in early stages of CRF insulin resistance might be associated with the well-known in-

Received: 23 May 1994 and in revised form: 26 September 1994

Corresponding author: Dr. I.Eidemak, Department of Nephrology B, Herlev Hospital, Herlev Ringvej, DK-2730 Herlev, Denmark

Abbreviations: CRF, Chronic renal failure; GFR, glomerular filtration rate; NEFA, non-esterified fatty acids; $\mathrm{CO}$, cardiac output; GH, growth hormone; OGTT, oral glucose tolerance test. creased cardiovascular risk factors in these patients, and could in theory be associated with the progression of renal disease.

Impaired physical fitness seems to be one important factor in the pathogenesis of insulin resistance, as observed in a variety of chronic diseases [6-9]. Furthermore, a strong correlation between tissue sensitivity to insulin and physical fitness has been documented in non-diabetic humans [10].

The current study was therefore undertaken to determine whether patients with mild to moderate progressive CRF are insulin resistant and hyperinsulinaemic, and, if so, whether this condition is associated with the patients' level of physical fitness. 
Table 1. Clinical characteristics of the patients and the control subjects

\begin{tabular}{lll}
\hline & $\begin{array}{l}\text { Patients } \\
n=29\end{array}$ & $\begin{array}{l}\text { Control subjects } \\
n=15\end{array}$ \\
\hline $\begin{array}{l}\text { Sex } \\
\text { (male/female) }\end{array}$ & $17 / 12$ & $7 / 8$ \\
Age (years) & $45(22-70)$ & $38(28-72)$ \\
$\begin{array}{l}\text { Height }(\mathrm{cm}) \\
\text { Weight }(\mathrm{kg})\end{array}$ & $174(157-186)$ & $169(155-189)$ \\
$\begin{array}{l}\text { BMI }\left(\mathrm{kg} / \mathrm{m}^{2}\right) \\
\text { Serum-crea- } \\
\text { tinine }(\mu \mathrm{mol} / \mathrm{l})\end{array}$ & $24(19-109)$ & $65(54-103)$ \\
$\begin{array}{l}\text { Serum-urea } \\
\text { (mmol/1) }\end{array}$ & $312(156-461)$ & $23(20-29)$ \\
$\begin{array}{l}\text { Haemoglobin } \\
\text { (mmol/1) }\end{array}$ & $70(49-111)^{\mathrm{a}}$ \\
$\begin{array}{l}\text { Blood pressure } \\
\text { (mmHg) }\end{array}$ & $140 / 84(5.6-24.5)$ & \\
\hline
\end{tabular}

Data given as median (range)

${ }^{a} p<0.01$ significantly different between patients and controls

\section{Subjects and methods}

Subjects. Twenty-nine non-diabetic patients with mild to moderate progressive CRF and 15 healthy subjects with normal renal function participated in the study. Clinical characteristics of patients and control subjects are given in Tables 1 and 2 . Twelve patients had polycystic kidney disease (verified by ultrasonography), six had hypertensive nephrosclerosis (verified by renal biopsy or made probable by a history of hypertension), five had chronic glomerulonephritis (verified by renal biopsy), three had chronic tubulo-interstitial nephropathy (made probable by history of pyelonephritis and radiologic features) and three had chronic nephropathy of unknown aetiology. Progressive loss of renal function was demonstrated by a negative slope of the reciprocal plasma creatinine against time in a preceding period of at least 1 year [11]. A total of 28 patients received antihypertensive medication, 22 patients were treated with angiotensin converting enzyme inhibitors alone or in combination with other drugs, 13 with beta-blockers and/or thiazides alone or in combination with other drugs. Five patients adhered to a diet of fixed protein with a protein intake of $0.5 \mathrm{~g} / \mathrm{kg}$ body weight (BW) daily for two patients, and an intake of $1 \mathrm{~g} / \mathrm{kgBW}$ daily for three patients. None of the patients were treated with erythropoietin. Patients treated with immunosuppressive medication, with known heart failure, or malignant disease were not included. Informed consent was obtained from all subjects and the study protocol was approved by the ethical committee of Copenhagen County, Denmark.

Metabolic investigations. The investigations started at 08.00 hours after an overnight fast. Patients were allowed to drink a small amount of water with their usual medication. All subjects were in the supine position in a quiet laboratory during the study period. An i.v. teflon cannula was inserted into an antecubital vein for blood sampling, and the arm was placed on a heating pad $\left(70^{\circ} \mathrm{C}\right)$. Another cannula was inserted into a contralateral antecubital vein for infusion of test substances.

The tissue sensitivity to insulin was assessed by the use of a 120-min euglycaemic hyperinsulinaemic clamp according to the technique of DeFronzo et al. [12] with minor modifications [13]. Insulin (25 IU Velosulin; Novo Nordisk A/S, Bagsvaerd, Denmark) was dissolved in $48 \mathrm{ml} \mathrm{NaCl}(154 \mathrm{mmol} / \mathrm{l})$ mixed with $2 \mathrm{ml}$ of blood taken from the proband. Insulin was administered at a rate of $2 \mathrm{mU} /(\mathrm{min} \cdot \mathrm{kg} \mathrm{BW})$ the first $10 \mathrm{~min}$ and subsequently at a constant rate of $1 \mathrm{mU} /(\mathrm{min} \cdot \mathrm{kg} \mathrm{BW})$. Blood glucose was kept constant at a euglycaemic level by infusion of a $20 \%$ glucose solution, infusion rate being adjusted according to on-line blood glucose measurements every $10 \mathrm{~min}$ in a blood glucose meter (Hypocount MX; Hypoguard (UK) Ltd, Melton, Suffolk, UK). Blood for determination of serum insulin and C-peptide was drawn after 30 min rest (baseline) and after 15, 60,90 and $120 \mathrm{~min}$. Plasma pancreatic glucagon, serum growth hormone (GH) and serum non-esterified fatty acids (NEFA) were measured at baseline and after $120 \mathrm{~min}$.

Glucose tolerance and insulin secretion was evaluated with the use of a 120-min oral glucose tolerance test (OGTT). A solution of $75 \mathrm{~g}$ glucose in $200 \mathrm{ml}$ water was given orally, and blood for determination of blood glucose, serum insulin and C-peptide was drawn at baseline and after 15, 30, 60, 90 and $120 \mathrm{~min}$.

Physiological investigations. Glomerular filtration rate (GFR) was estimated by the plasma clearance of ${ }^{51} \mathrm{Cr}$-EDTA. All subjects were studied in the supine position. Between 08.00 and 09.00 hours a bolus injection of $4 \mathrm{MBq}{ }^{51} \mathrm{Cr}$-EDTA was given intravenously. An expected GFR was estimated on the basis of sex, age, body weight, and the plasma concentration of creatinine [14]. In the case of an expected GFR above $15 \mathrm{ml} / \mathrm{min}$, ${ }^{51} \mathrm{Cr}$-EDTA plasma clearance was calculated on the basis of plasma activity in four blood"samples drawn at 20-min intervals in the $4^{\text {th }} \mathrm{h}$ following the injection [11]. When GFR was estimated to be below $15 \mathrm{ml} / \mathrm{min}$ blood samples were drawn at 5 and $24 \mathrm{~h}$ after injection. Clearance was calculated according to Brøchner-Mortensen $[15,16]$. The reliability of this method in predicting GFR of the individual patient is $\pm 0.5 \mathrm{ml} / \mathrm{min}$ [16].

The exercise test was performed on an electrically braked bicycle ergometer (MedGraphics CPE 2000), which was coupled to a cardiopulmonary gas exchange system (CPX,MAX from Med-Graphics (Medical Graphics Corporation, St.Paul, Minn., USA)) and in microcomputer for on-line calculations. Blood pressure was measured auscultatorily with a pressure cuff around the upper arm connected to a mercury sphygmomanometer. Diastolic blood pressure was recorded when the Korotkoff sounds disappeared. A 12-lead electrocardiogram was recorded at rest in the supine position and during the test. After an initial warm-up period of 6 min at a work load of $40 \mathrm{~W}$, the work load was gradually increased by $10-20 \mathrm{~W} / \mathrm{min}$ until subjective exhaustion. $\mathrm{O}_{2}$-uptake and $\mathrm{CO}_{2}$-production were measured continuously (breath-by-breath) by the cardiopulmonary gas exchange CPX/MAX system at supine rest and during exercise. The peak value (averaged for eight breaths) was used as $\mathrm{VO}_{2}$ max, peak heart rate as maximal heart rate. Maximal blood pressure was measured approximately $1 \mathrm{~min}$ before exhaustion. Cardiac output $(\mathrm{CO})$ was measured at rest with the $\mathrm{CO}_{2}$ rebreathing method [17], using the above mentioned equipment and stroke volume was calculated by division with simultaneously recorded heart rate.

Analytical procedures. Blood glucose was analysed using the glucose oxidase method with an oxygen electrode. Serum insulin was analysed by an ELISA-method employing polyclonal antibodies [18], serum C-peptide by a radioimmunoassay method as described by Heding [19] employing the antibody M1230 [20] and plasma glucagon was measured as described by Ørskov et al. [21] with minor modifications. Serum GH 
Table 2. Individual cases of patient characteristics and results

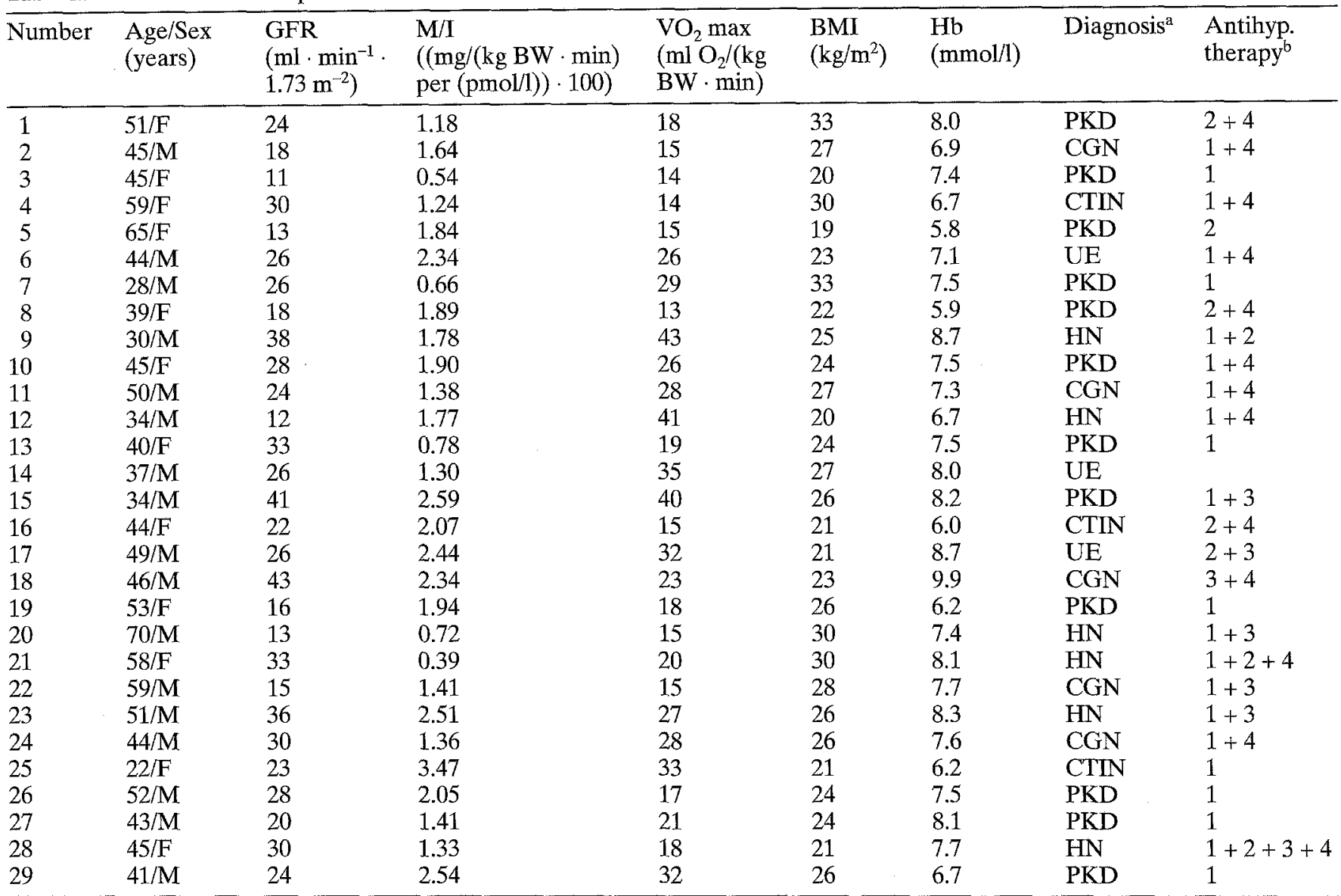

a Diagnosis: PKD, Polycystic kidney disease; HN, hypertensive $\quad{ }^{\mathrm{b}}$ Antihypertensive therapy: 1 ACE inhibitor, 2 beta-blocker, nephrosclerosis; CGN, chronic glomerulonephritis; CTIN, 3 Thiazides, 4 Other chronic tubulo-interstitial nephropathy; UE, chronic nephropathy of unknown aetiology
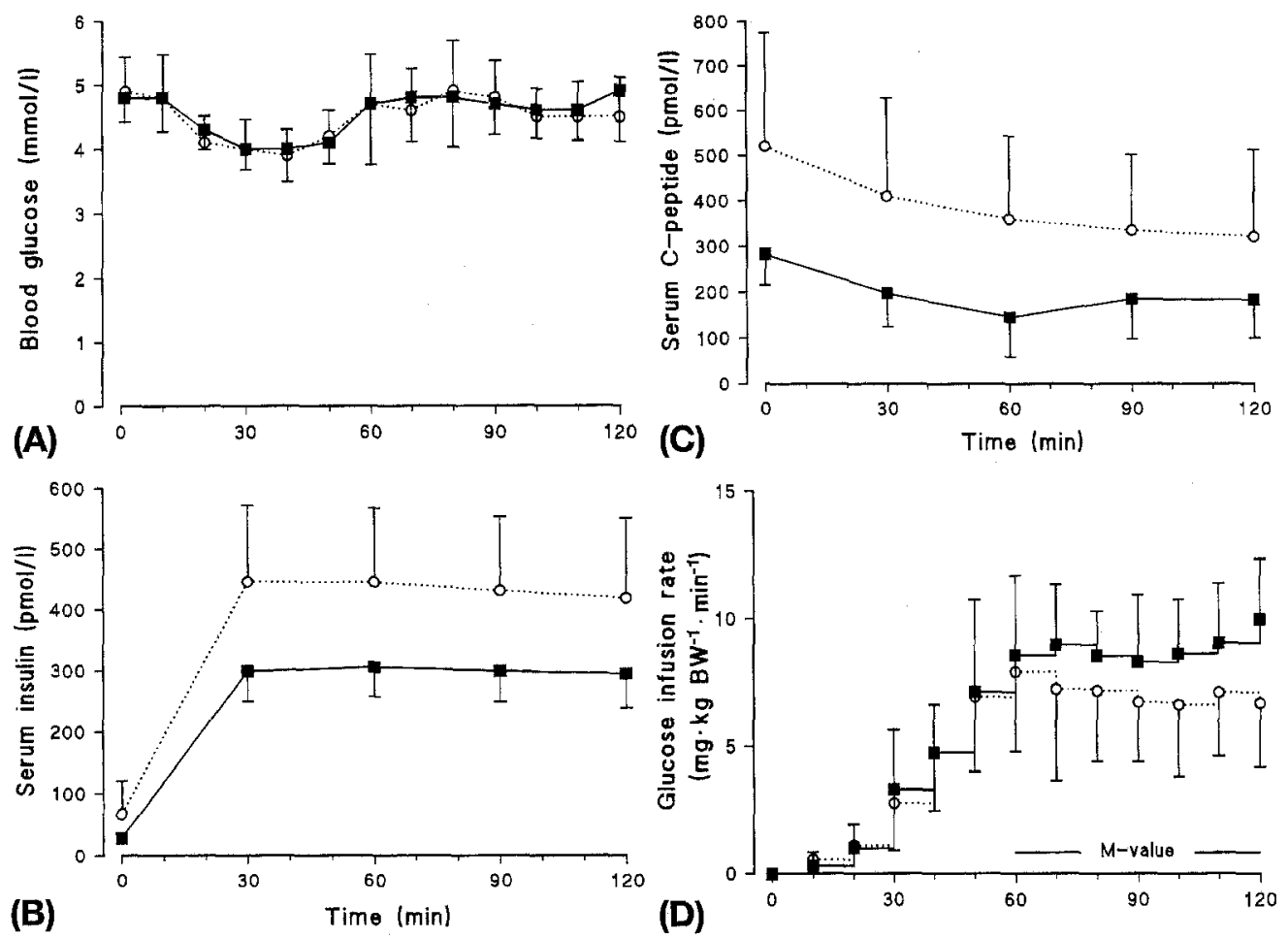

Fig.1(A-D). Summary of steady-state blood-glucose (A), serum insulin (B), serum C-peptide (C) and glucose infusion rate (D) during the hyperinsulinaemic euglycaemic clamp. Twenty-nine patients $O$ and 15 control subjects $\mathbf{E}$ were investigated. Results are shown as mean $\pm \mathrm{SD}$ 


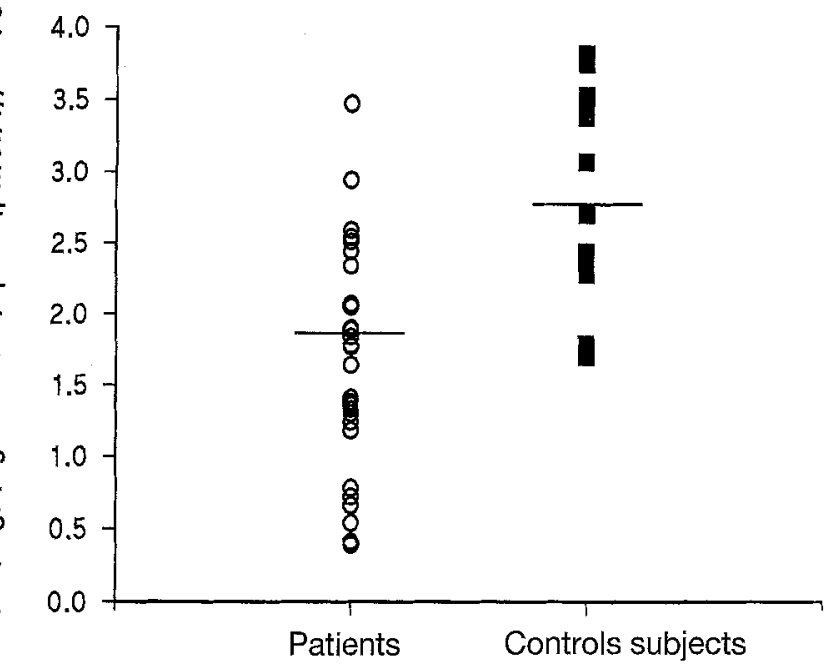

Fig. 2. $\mathrm{M} / \mathrm{I}$ ratio in patients $O$ and control subjects
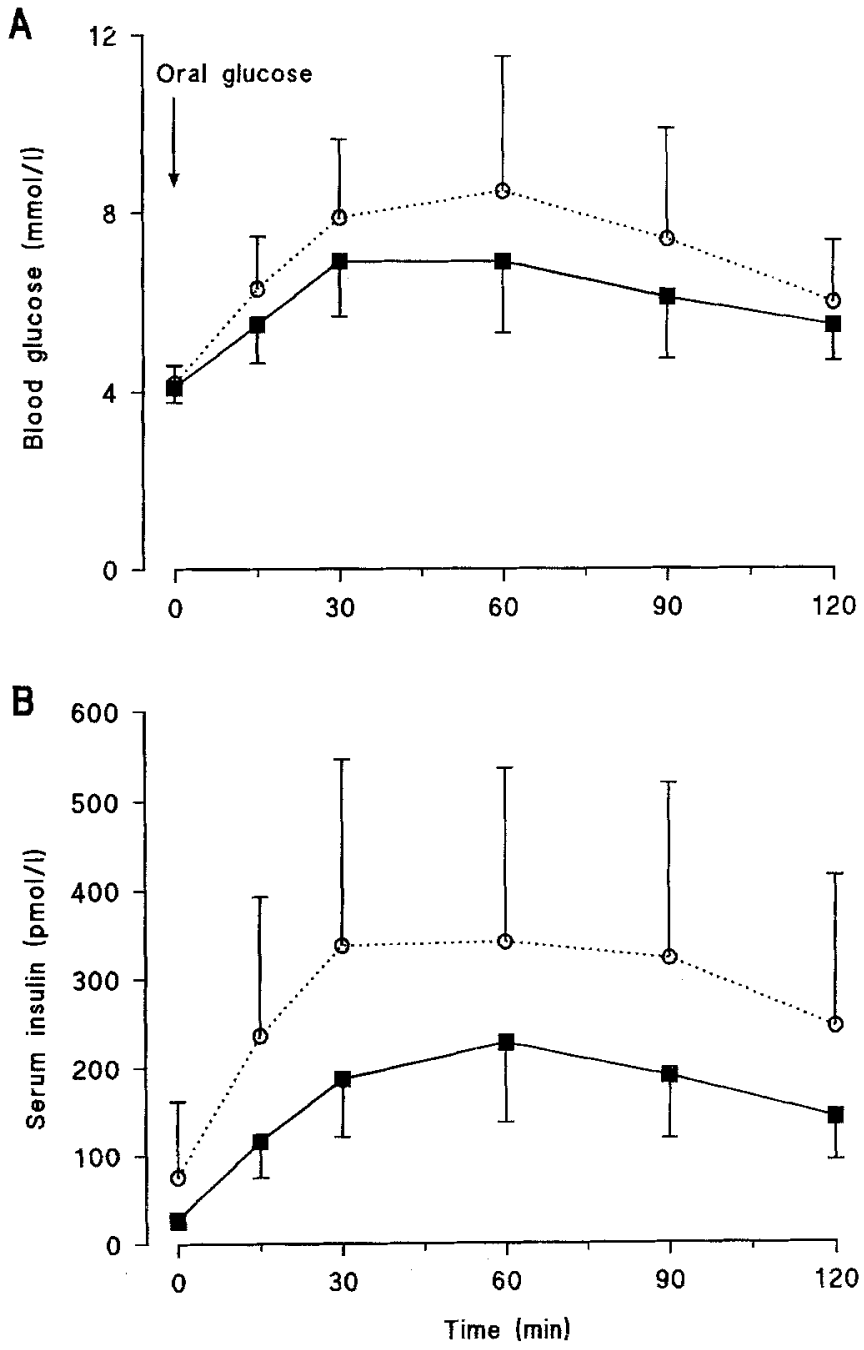

Fig.3. A, B. Blood glucose and serum insulin response to a 75 -g oral glucose tolerance test in 29 patients $\bigcirc$ and 15 control subjects 1 . Results are shown as mean \pm SD
Table 3. Counterregulating hormones and NEFA: hyperinsulinaemic euglycaemic insulin clamp

\begin{tabular}{|c|c|c|c|c|}
\hline & \multirow{2}{*}{\multicolumn{2}{|c|}{$\begin{array}{l}\text { Time } \\
0 \\
(\min )\end{array}$}} & \multicolumn{2}{|l|}{ Time } \\
\hline & & & \multirow{2}{*}{$\begin{array}{l}120 \\
(\mathrm{~min}) \\
\text { Patients }\end{array}$} & \multirow{2}{*}{$\begin{array}{l}\begin{array}{l}\text { Ov120 } \\
\text { (min) }\end{array} \\
\text { Control } \\
\text { Subjects }\end{array}$} \\
\hline & Patients & $\begin{array}{l}\text { Control } \\
\text { Subjects }\end{array}$ & & \\
\hline $\begin{array}{l}\mathrm{GH} \\
(\mathrm{ng} / \mathrm{ml})\end{array}$ & $\begin{array}{l}1.47 \\
(2.38)\end{array}$ & $\begin{array}{l}0.97 \\
(2.55)\end{array}$ & $\begin{array}{l}2.47 \\
(4.81)\end{array}$ & $\begin{array}{l}0.95 \\
(0.97)\end{array}$ \\
\hline $\begin{array}{l}\text { Glucagon } \\
(\mathrm{pg} / \mathrm{ml})\end{array}$ & $\begin{array}{l}74 \\
(35)\end{array}$ & $\begin{array}{l}30^{\mathrm{a}} \\
(7)\end{array}$ & $\begin{array}{l}56^{\mathrm{a}} \\
(31)\end{array}$ & $\begin{array}{l}20^{\mathrm{a}, \mathrm{c}} \\
(10)\end{array}$ \\
\hline $\begin{array}{l}\mathrm{NEFA} \\
(\mathrm{mmol} / \mathrm{l})\end{array}$ & $\begin{array}{l}382 \\
(163)\end{array}$ & $\begin{array}{l}432 \\
(159)\end{array}$ & $\begin{array}{l}46^{\mathrm{b}} \\
(28)\end{array}$ & $\begin{array}{l}49^{c} \\
(98)\end{array}$ \\
\hline $\begin{array}{l}\text { NEFA } \\
(\%)\end{array}$ & reduction & & $\begin{array}{l}85 \% \\
(13)\end{array}$ & $\begin{array}{l}91 \% \\
(11)\end{array}$ \\
\hline
\end{tabular}

Mean (SD).

a $p<0.01$ between patients and control subjects

${ }^{\mathrm{b}} p<0.01$ between time 0 and $120 \mathrm{~min}$ in patients

${ }^{c} p<0.01$ between time 0 and $120 \mathrm{~min}$ in control subjects

was analysed using an immunofluorometric sandwich assay with two monoclonal antibodies (Delfia, hGH kit, Wallac Oy, Turku, Finland), and serum NEFA was determined by a colorimetric method employing a commercial kit (WacoChemical, Neuss, Germany).

\section{Statistical analysis}

Data are given as median with range (clinical characteristics) or as mean \pm SD (results, corresponding to figures). The unpaired non-parametric Mann-Whitney test was used to compare values from patients with values different from the control subjects. Multiple regression analysis was performed using a least square method. A two-tailed $p$-value less than 0.05 was considered to be statistically significant.

\section{Results}

Hyperinsulinaemic euglycaemic insulin clamp. Basal blood glucose levels did not differ between patients $(4.9 \pm 0.5 \mathrm{mmol} / \mathrm{l})$ and control subjects (4.8 \pm $0.4 \mathrm{mmol} / \mathrm{l}$ ), and blood glucose during "steady state" $(60-120 \mathrm{~min})$ was maintained at $4.7 \pm 0.3 \mathrm{mmol} / \mathrm{l}$ in patients and $4.8 \pm 0.3 \mathrm{mmol} / \mathrm{l}$ in control subjects. The coefficient of variation of the blood glucose values measured every $10 \mathrm{~min}$ were $11 \pm 7$ vs $11 \pm 5 \%$ (Fig. 1 a). Basal insulin values were higher in patients than in control subjects ( $68 \pm 53$ vs $28 \pm 8 \mathrm{pmol} / 1$, $p<0.01)$ and when insulin was infused at a rate of $1 \mathrm{mV} \cdot \mathrm{kg} \mathrm{BW}{ }^{-1} \cdot \mathrm{min}^{-1}$ steady state serum insulin concentrations averaged $432 \pm 126 \mathrm{pmol} / 1$ in patients and $300 \pm 52 \mathrm{pmol} / \mathrm{l}$ in control subjects (Fig. $1 \mathrm{~b}$ ). Cpeptide was significantly suppressed in both groups during the clamp $(p<0.01)$ indicating that endogenous insulin secretion was suppressed (Fig. 1c). The amount of exogenous glucose required to maintain 
Table 4. Cardiovascular results at rest and during exercise

\begin{tabular}{|c|c|c|c|c|c|c|c|c|}
\hline & $\begin{array}{l}\mathrm{CO} \\
\left(1 \cdot \min ^{-1}\right)\end{array}$ & $\begin{array}{l}\text { SV } \\
(\mathrm{ml})\end{array}$ & $\begin{array}{l}\text { HR rest } \\
\text { HR max } \\
(\mathrm{bpm})\end{array}$ & $\begin{array}{l}\mathrm{VO}_{2 \max } \\
\left(1 \cdot \min ^{-1}\right)\end{array}$ & $\begin{array}{l}\mathrm{VO}_{2 \max } / \mathrm{BW} \\
\left(\mathrm{ml} \cdot \min ^{-1} \cdot \mathrm{kg}^{-1}\right)\end{array}$ & $\begin{array}{l}\text { Maximal } \\
\text { workload } \\
\text { (Watt) }\end{array}$ & $\begin{array}{l}\text { BP rest } \\
(\mathrm{mmHg})\end{array}$ & $\begin{array}{l}\mathrm{BP}_{\max } \\
(\mathrm{mmHg})\end{array}$ \\
\hline $\begin{array}{l}\text { Control subjects } \\
n=15\end{array}$ & $4.8(0.7)$ & $71(21)$ & $\begin{array}{c}71(13) \\
176(14)^{\mathrm{a}}\end{array}$ & $2.29(1.07)$ & $31(11)^{b}$ & $170(66)^{\mathrm{c}}$ & $119 / 70(11 / 20)^{\mathrm{a}}$ & $168 / 89(17 / 8)$ \\
\hline
\end{tabular}

Mean (SD) ${ }^{a} p<0.01 ;{ }^{b} p<0.02 ;{ }^{c} p<0.03$ significantly different between patients and control subjects.

Table 5. Maximal heart rate and maximal aerobic work capacity in patients treated with or without beta-blockers

\begin{tabular}{|c|c|c|c|}
\hline & \multicolumn{3}{|l|}{ Patients } \\
\hline & $\begin{array}{l}\text { With } \beta \text { - } \\
\text { blockers } \\
(n=9)\end{array}$ & $\begin{array}{l}\text { No } \beta- \\
\text { blockers } \\
(n=20)\end{array}$ & $p$ value \\
\hline Heart rate $\max (\mathrm{bpm})$ & $125(15)$ & $155(24)$ & $<0.01$ \\
\hline $\begin{array}{l}\mathrm{VO}_{2} \mathrm{max} / \text { body weight } \\
\left(\mathrm{ml} \cdot \mathrm{min}^{-1} \cdot \mathrm{kg}^{-1}\right)\end{array}$ & $21(10)$ & $26(8)$ & NS \\
\hline
\end{tabular}

Mean (SD)

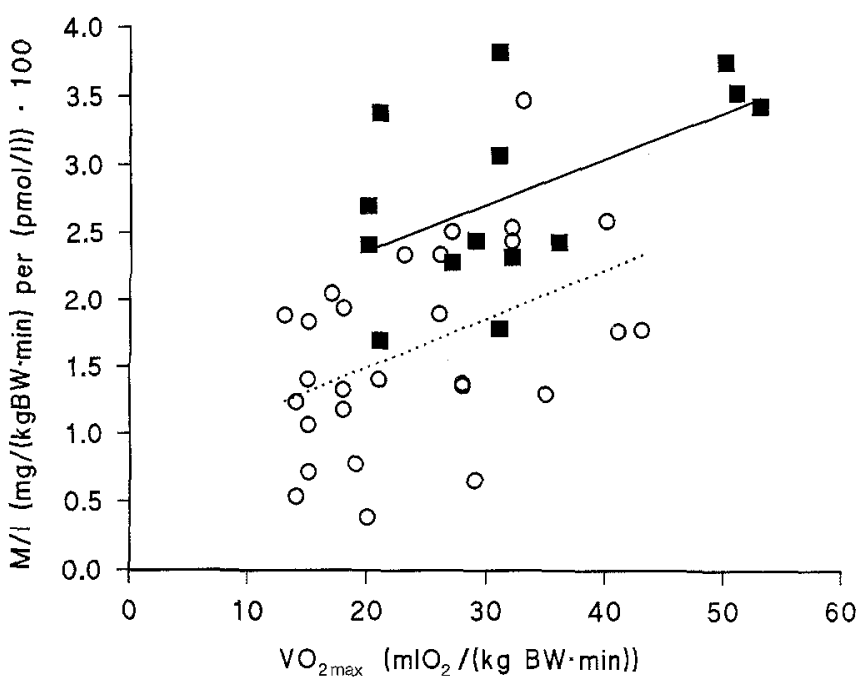

Fig.4. Maximal aerobic work capacity $\left(\mathrm{VO}_{2 \max }\right)$ plotted against the $\mathrm{M} / \mathrm{I}$ ratio. Patients $O \cdots(r=0.45, p<0.02)$, control subjects $\square-(r=0.60, p<0.05)$

the glucose levels constant during last 60 min of the clamp (M-value) was significantly smaller in the patients than in the control subjects $(404 \pm 118$ vs $494 \pm 85 \mathrm{mg}$ glucose/kg BW, $p<0.02$ ) (Fig. $1 \mathrm{~d}$ ), and the ratio of glucose uptake to steady-state insulin concentration, $\mathrm{M} / \mathrm{I}$ ratio, was approximately $30 \%$ lower in the patients than in the control group $(1.77 \pm 0.71$ vs $2.57 \pm 0.70(\mathrm{mg} / \mathrm{kg} \mathrm{BW} \cdot \mathrm{min})$ per $\mathrm{pmol} / \mathrm{l}) \cdot 100, p<0.001$ ) (Fig. 2). There was no difference in $\mathrm{M}$-values between the 12 patients treated with beta-blockers and/or thiazides and the 16 pa-
$\mathrm{CO}$, Cardiac output; SV, stroke volume; HR heart rate; $\mathrm{VO}_{2} \max$, maximal oxygen consumption, $\mathrm{VO}_{2} \mathrm{max} / \mathrm{BW}$, maximal aerobic work capacity

tients treated with other drugs $(404 \pm 112$ vs $404 \pm 118 \mathrm{mg}$ glucose $/ \mathrm{kg} \mathrm{BW}, \mathrm{NS}$ ) or between three moderately glucose intolerant patients (see below) and the rest of the patients ( $392 \pm 66 \mathrm{vs} 405 \pm 123 \mathrm{mg}$ glucose $/ \mathrm{kg} \mathrm{BW}, \mathrm{NS}$ ). Basal GH levels were similar in the two groups and the levels did not change during the clamp (Table 3). Basal plasma glucagon was twice as high in patients as in control subjects $(p<0.01)$, and insulin infusion was followed by a suppression of plasma levels in both groups $(p<0.01)$ (Table 3). Basal serum NEFA and the decrease in NEFA levels during insulin infusion were comparable in patients and control subjects, and all subjects showed a pronounced fall in serum NEFA during the clamp $(p<0.01)$ (Table 3$)$.

Oral glucose tolerance test. Fasting blood glucose did not differ between patients and control subjects ( $4.1 \pm 0.3$ vs $4.3 \pm 0.4 \mathrm{mmol} / \mathrm{l})$ and again basal serum insulin levels were significantly higher in patients than in control subjects $(p<0.01)$. After the oral glucose load both groups showed an equal and non diabetic glucose-curve (blood glucose area) (Fig. $3 \mathrm{a}$ ), but three patients were moderately glucose intolerant in terms of a slightly elevated blood glucose at $120 \mathrm{~min}$ (8.1, 9.7 and $9.8 \mathrm{mmol} / 1$, respectively). The rise in insulin (insulin-area) following the glucose load was markedly increased in the patients $(p<0.02)$ (Fig. 3b).

The OGTT preceded the hyperinsulinaemic euglycaemic insulin clamp in all cases. The time interval between the two tests were no less than 6 days.

Glomerular filtration rate. In the patient group median GFR was $25(11-43) \mathrm{ml} \cdot \mathrm{min}^{-1} \cdot 1.73 \mathrm{~m}^{-2}$. All control subjects had normal renal function 94 (73-119) $\mathrm{ml} \cdot \mathrm{min}^{-1} \cdot 1.73 \mathrm{~m}^{-2}$.

Aerobic work capacity and cardiac performance. Resting CO, heart rate (HR rest) and stroke volume (SV) were similar in patients and control subjects (Table 4). The electrocardiogram at rest and in response to exercise was normal in all subjects. Diastolic as well as systolic blood pressure were higher in patients than in control subjects at rest but the level 
during exercise was not different in the two groups (Table 4). During the exercise test, maximal attainable work load, maximal heart rate (HR max) and maximal aerobic work capacity $\left(\mathrm{VO}_{2 \max } \cdot \mathrm{kg} \mathrm{BW}^{-1}\right)$ were significantly lower in patients than in control subjects (Table 4). Patients treated with beta-blockers had a significantly $(p<0.01)$ lower maximal heart rate compared to patients treated with other antihypertensive medication. Despite this difference maximal aerobic work capacity did not differ significantly between the two groups of patients (Table 5). The relation between insulin sensitivity (M/I ratio) and $\mathrm{VO}_{2 \max } \cdot \mathrm{kg} \mathrm{BW}^{-1}$, GFR and haemoglobin concentration was assessed by multiple regression analysis. M/I ratio was positively correlated to $\mathrm{VO}_{2 \max } \cdot \mathrm{kg} \mathrm{BW}^{-1}$ in patients $(r=0.45, p<0.02)$ as well as in control subjects $(r=0.60, p<0.05$ ) (Fig. 4$)$, whereas there was no significant correlation between $M / I$ ratio and GFR or haemoglobin concentration.

\section{Discussion}

In the present study it was shown that compared to a group of healthy individuals, patients with mild to moderate progressive CRF were insulin resistant and hyperinsulinaemic despite a generally normal glucose tolerance test. This state of insulin resistance in the patients was correlated to their relatively poor physical fitness.

All patients suffered from progressive CRF caused by a variety of diseases, with a better kidney function than in previous studies of uraemic insulin resistance.

Patients and control subjects were carefully matched with respect to age, sex, and body mass index. Blood pressure was significantly higher in the patients than in the control subjects and 28 patients received antihypertensive medication.

The validity of the present observations obviously rests on the methods used for assessing insulin sensitivity, glucose tolerance and insulin production. The euglycaemic hyperinsulinaemic clamp technique as used in our study is advantageous when compared to other techniques for assessing insulin sensitivity [13]. In the present study we administered a dose of insulin which sufficiently suppressed the hepatic glucose production to insignificant values $[4,22]$. Serum insulin was raised from the basal value and was maintained at a new plateau in both groups while blood glucose was maintained at a constant euglycaemic level. The insulin dose was identical in patients and control subjects but the patients had a significantly higher serum insulin level than control subjects during the clamp period, probably due to a reduced renal degradation of insulin [23, 24]. Despite this unintended high insulin level, the glucose infusion rate needed to maintain euglycaemia (M-value) and the ratio of glucose uptake to steady-state insulin concentration (M/I) ratio both were significantly lower in the patient group than in the control group, indicating insulin resistance. Serum C-peptide was significantly suppressed in both groups indicating that the endogenous insulin production had been suppressed, and hypoglycaemia did not occur in any subjects during the study. This finding of our patients with only mild to moderate CRF is in agreement with previous observations in patients with end-stage CRF [2-12].

An OGTT was performed to evaluate glucose tolerance and insulin response to glucose. All but three patients had a normal OGTT. In contrast, more than $50 \%$ of patients with end-stage CRF have a considerably reduced glucose tolerance $[1,22,25]$. The basal serum insulin level as well as the insulin response to an oral glucose load was significantly higher in patients than in control subjects. Although this difference could in part be explained by reduced renal degradation of insulin, part of the difference is probably caused by hypersecretion of insulin, since patients are at the same time insulin resistant and glucose tolerant. Conflicting data have been reported on the sensitivity of the beta cell in response to a glucose load in patients with terminal CRF. In a study by Alvestrand et al. [25] three groups of patients on chronic haemodialysis had either normal, borderline or decreased glucose tolerance. Despite a similar degree of insulin resistance between the groups, those with normal glucose tolerance had the highest insulin response. The presence of borderline glucose intolerance in three patients in the present study did not appear to add to insulin resistance.

Insulin resistance in CRF could theoretically be due to increased plasma concentrations of the counteracting hormones $\mathrm{GH}$ and glucagon as well as NEFA. GH levels were normal in our patients both basally and during hyperinsulinaemia and thus did not seem to contribute to insulin resistance. In contrast GH levels are elevated in patients with endstage CRF [3]. Basal plasma glucagon was considerably elevated in our patients and significantly suppressed during the clamp in both groups. This finding is in agreement with results of previous studies in patients with end-stage CRF [3] and would seem to rule out that hyperglucagonaemia contributes to the insulin resistance. Basal serum NEFA as well as the suppression during insulin infusion were identical in the two groups, as found in other studies [3].

Maximal aerobic work capacity was significantly lower in patients as compared to the healthy control group, and was obtained at a significantly lower maximal workload and heart rate. Treatment with betablockers reduces exercise heart rate and might reduce maximal $\mathrm{O}_{2}$ uptake. However in untrained subjects such as our patients beta-blocker-mediated reduction in heart rate has a minimal effect on maximal $\mathrm{O}_{2}$ uptake [26]. In patients as well as in the con- 
trol subjects maximal aerobic work capacity was positively correlated to insulin sensitivity. A similar correlation bas previously been found in healthy humans [10]. The effect of acute and long-term exercise on insulin resistance has been studied intensively in healthy as well as in insulin-resistant subjects [6-8, 10, 23-30]. In the study by Holloszy et al. [6] patients with non-insulin-dependent diabetes or glucose intolerance were intensively exercise trained for 1 year resulting in a marked improvement in glucose tolerance and reduced insulin secretion. Goldberg et al. [9] found that long-term exercise training in patients on haemodialysis improve the work capacity by 10 $20 \%$. This improvement was associated with a significant reduction in blood glucose levels, an improvement in glucose disappearance rate and reduction in fasting insulin. On the basis of our results and other studies it appears likely that impaired physical fitness could contribute to the insulin resistance in our patients.

Thirteen patients were treated with beta-blockers and/or thiazides due to hypertension. Prolonged treatment with both groups of drugs is known to have a negative influence on glucose metabolism [31, 32]. In the present study there was no difference in insulin sensitivity between patients treated with these drugs and the rest of the patient group. One explanation could be that seven of the beta-blocker/thiazide treated patients in addition recived angiotensin converting enzyme inhibitors, drugs with a potentially positive influence on glucose metabolism [33, 34].

The consequence of insulin resistance and hyperinsulinaemia in patients with CRF is unknown. As in other insulin-resistant conditions such as noninsulin-dependent diabetes and essential hypertension, insulin resistance and the compensatory hyperinsulinaemia may play a role in the development of cardiovascular complications [35-37].

In conclusion, the present study demonstrated the presence of insulin resistance and hyperinsulinaemia in patients with mild to moderate chronic renal failure. The influence of physical fitness was separately assessed and maximal aerobic work capacity was significantly lower in patients as compared to control subjects and furthermore positively correlated to the tissue sensitivity to insulin. These observations indicate that poor physical fitness at least in part could be responsible for the presence of insulin resistance, and exercise training might be an important component of the treatment of patients with chronic renal failure.

Acknowledgements. The authors thank Ms. B. Svensson for her expert technical assistance and the laboratory of Dr. C. Binder, Steno Diabetes Center for analysis of the insulin assay. The work was supported by The University of Copenhagen (research grant), The Medical Foundation of Greater Copenhagen, Faroe Islands and Greenland, Lilly Bertine Lund's Foundation, The Danish Kidney Foundation and the NOVO Foundation.

\section{References}

1. Horton ES, Johnson C, Lebovitz HE (1968) Carbohydrate metabolism in uraemia. Ann Intern Med 68: 63-74

2. DeFronzo RA, Tobin JD, Rowe JW, Andres R (1978) Glucose intolerance in uraemia. J Clin Invest 62: 425-435

3. Schmitz O, Alberti KGMM, Christensen NJ et al. (1985) Aspects of glucose homeostasis in uraemia as assessed by the hyperinsulinemic euglycemic clamp technique. Metabolism 34: $465-473$

4. DeFronzo RA, Alvestrand A, Smith D, Hendler R, Hendler $\mathrm{E}$, Wahren J (1981) Insulin resistance in uraemia. J Clin Invest $67:$ 563-568

5. Westrevelt FB (1968) Abnormal carbohydrate metabolism in uraemia. Am J Clin Nutr 21: 423-425

6. Holloszy JO, Schultz J, Kusnierkiewicz J, Hagberg JM, Ehsani AA (1986) Effects of exercise on glucose tolerance and insulin resistance. Acta Med Scand [Suppl] 711: $55-65$

7. Devlin JT, Horton ES (1985) Effect of prior high-intensity exercise on glucose metabolism in normal and insulin resistant men. Diabetes 34: 973-979

8. DeFronzo RA, Sherwin RS, Kraemer N (1987) Effect of physical training on insulin action in obesity. Diabetes 36 : 1379-1385

9. Goldberg AP, Geltman EM, Gavin JR et al. (1986) Exercise training reduces coronary risk and effectively rehabilitates hemodialysis patients. Nephron 42: 311-316

10. Rosenthal M, Haskell WL, Salomon R, Widstrom A, Reaven GM (1983) Demonstration of a relationship between level of physical training and insulin-stimulated glucose utilization in normal humans. Diabetes 32: 408-411

11. Mitch WE, Walser M, Buffington GA, Lemann J (1976) A simple method of estimating progression of chronic renal failure. Lancet 2: 1326-1328

12. DeFronzo RA, Tobin JD, Andres R (1979) Glucose clamp technique: a method for quantifying insulin secretion and resistance. Am J Physiol 237: E214-E223

13. Thorsteinsson B, Fugleberg S, Feldt-Rasmussen B, Ellemann K, Andersen OO, Binder C (1987) Kinetic models for insulin disappearance from plasma in type I diabetes patients. Acta Pharmacol et Toxicol 60: 90-95

14. Kampmann J, Siersbæk-Nielsen K, Kristensen M, Mølholm-Hansen J (1974) Rapid evaluation of creatinine clearance. Acta Med Scand 198: 517-520

15. Brøchner-Mortensen J (1972) A simple method for the determination of glomerular filtration rate. Scand J Clin Lab Invest 30: 271-274

16. Brøchner-Mortensen J (1981) Reliability of routine clearance methods of assessment of glomerular filtration rate in advanced renal insufficiency. Scand J Clin Lab Invest 41: 91-97

17. Espersen K, Jensen EW, Rosenborg D et al. (1994) Cardiac output measured by thermodilution, Doppler and $\mathrm{CO}_{2}$-rebreathing technique compared with the direct Fick method. Acta Anæst Scand

18. Lanng S, Thorsteinsson B, Røder ME et al. (1993) Pancreas and gut hormone response to oral glucose and intravenous glucagon in cystic fibrosis patients with normal, impaired, and diabetic glucose tolerance. Acta Endocrinol 128: 207214

19. Heding LG (1975) Radioimmunological determination of human C-peptide in serum. Diabetologica 11: 541-548

20. Faber OK, Markussen J, Naithani VK, Binder C (1976) Production of antisera to synthetic benzyloxycarbonyl-Cpeptide of human proinsulin. Hoppe-Seyler's Z Physiol Chem 357: 751-757 
21. Ørskov H, Thomsen AG, Yde H (1968) Wick-chromatography for rapid and reliable immunoassay in insulin, glucagon and growth hormone. Nature 219: 193-195

22. Smith D, DeFronzo RA (1982) Insulin resistance in uraemia mediated by postbinding defects. Kidney Int 22: 54-62

23. Rubkin R, Simon NM, Steiner S, Colwell JM (1970) Effect of renal disease on renal uptake and excretion of insulin in man. N Engl J Med 282: 182-187

24. Rubkin R, Ryan MP, Duckworth WC (1984) The renal metabolism of insulin. Diabetologia 27: 351-357

25. Alvestrand A, Mujagic M, Wajngot A, Efendic S (1989) Glucose intolerance in uremic patients: the relative contribution of impaired $\beta$-cell function and insulin resistance. Clin Nephrol 31: 175-183

26. Joyner MA, Freund BJ, Jilka SM, Hetrick GA, Ewy GA, Wilmore JH (1986) Effects of $\beta$-blockade on exercise capacity of trained and untrained men: a hemodynamic comparison. J Appl Physiol 60(4): 1429-1434

27. DeFronzo RA, Andres R, Edgar P, Walker WG (1973) Carbohydrate metabolism in uremia: a review. Medicine 52: 469-481

28. Castellino P, Bia M, DeFronzo RA (1987) Metabolic response to exercise in dialysis patients. Kidney Int 32: $877-$ 883

29. Bjørntorp P, Berchtold P, Grimby G et al. (1972) Effects of physical training on glucose tolerance. Acta Med Scand 192: 439-443
30. Mikines KJ, Sonne B, Farrell PA, Tronier B, Galbo H (1988) Effect of physical exercise on sensitivity and responsiveness to insulin in humans. Am J Physiol 254: E248E259

31. Pollare T, Lithell H, Selinus I, Berne C (1989) Sensitivity to insulin during treatment with atenolol and metoprolol: a randomised, double blind study of effects on carbohydrate and lipoprotein metabolism in hypertensive patients. BMJ 298: 1152-1157

32. Pollare T, Lithell H, Berne C (1989) A comparison of the effects of hydrochlorothiazide and captopril on glucose and lipid metabolism in patients with hypertension. $\mathrm{N}$ Engl J Med 321: 868-873

33. Jauch K-W, Hartl W, Guenther B, Wicklmayr M, Rett K, Dietze G (1987) Captopril enhances insulin responsiveness of forearm muscle tissue in non-insulin-dependent diabetes mellitus. Eur J Clin Invest 17: 953-959

34. Prisant LM, Carr AA (1992) Antihypertensive drug therapy and insulin resistance. AJH 5: 775-777

35. DeFronzo RA, Ferrannini E (1991) Insulin resistance. Diabetes Care 14(3): 173-194

36. Frayn KN, Coppack SW (1992) Insulin resistance, adipose tissue and coronary heart disease. Clin Sci 82:1-8

37. Ma KW, Greene EL, Raij L (1992) Cardiovascular risk factors in chronic renal failure and hemodialysis patients. Am J Kidney Dis 19: 505-513 